\title{
A POSSIBLE METHOD OF DEALING WITH THE CLOSED SHOP ISSUE
}

\author{
Paul H. Douglas*
}

HE issue of the closed shop is one of the most hotly contested
and perplexing in the whole field of industrial relations. The ad-
vocates of the closed shop believe that it is necessary in order to protect union members from being gradually weeded out by employers through lay-offs and discharges and to prevent their replacement by nonunionists. Further, it is necessary in order that all workers contribute to the support of the organization which acts for them in grievance matters and which helps to reduce hours and obtain better working conditions for them. If this is not done, the supporters of the closed shop allege that the lazy and indifferent will reap without sowing and will either not join or will drop out of the unions and hence will allow the burden of expense and effort to be borne by the self-sacrificing and idealistic minority.

The opponents of the closed shop, on the other hand, object to it on the ground that it can be used to help saddle inefficiencies upon industry which will in the long run be adverse to labor, to employers, and to the consuming public, and that it is improper to force anyone against his will to join a union as a condition of obtaining or retaining employment.

The arguments which are used in support of these positions are cogent and weighty. Neither side, however, seems able to make many converts among those who hold to an opposing point of view and on this level the discussion often seems to have come to an intellectual stalemate.

Before turning to a possible reconciliation of these opposite sets of values and interests, it is perhaps appropriate to discuss briefly the changes which have been introduced by the National Labor Relations Act and also to review various devices which have been developed to soften the impact of the closed shop.

There would seem to be little doubt that the Wagner Act has somewhat weakened the case for the closed shop. Thus the act provides that it is an unfair practice for an employer:

(I) "to interfere with, restrain, or coerce employees" in the exercise of their right to unionize and bargain collectively, or

(2) to encourage or discourage membership in any labor organization

* Professor of Economics, University of Chicago. 
by "discrimination in regard to hire or tenure of employment or any term or condition of employer."

If it can be proved that a union man has been discriminated against because of these reasons, the National Labor Relations Board can order him reinstated and paid damages equal to the wages he has lost. The employers, therefore, cannot legally use their power of discharge to break up a union. Has not the main reason for the closed shop therefore been removed?

While there is some force to this contention, it would seem to be only partially true. For in the first place, the law can only sift out and deal with the most obvious cases of discriminatory discharge. There is a fine art to getting rid of men whom one dislikes and most employers and managers are rapidly becoming expert practitioners of this art.

A second point is connected with lay-offs caused by seasonal or cyclical declines in business. At such times it is easy for the employers, unless restrained by other rules, to pay off old scores and guard against future dangers by concentrating the lay-offs from among the active union men. This is especially hard to detect and to prevent when a large number are being laid off. This tendency can indeed be checked by the introduction of seniority systems and this is perhaps the chief driving force behind the establishment of such systems. But so far as my observation goes, the introduction of seniority systems generally, although by no means universally, follows the establishment of the closed shop and is a further manifestation of increasing union control. It is doubtful if seniority would be widely adopted were unions to be weak. And it is because the proponents of the closed shop want to make unions strong that they insist upon it.

If the Wagner Act has somewhat weakened the arguments of the advocates of the closed shop, certain modifications in that institution should have softened some of the objections of its opponents. Thus it was over thirty-five years ago at the instance of the late Louis D. Brandeis that the famous protocol for the women's clothing industry provided that in hiring, union men should be preferred, but that ${ }^{\mathrm{x}}$ "employers shall have freedom of selection as between one union man and another and shall not be confined to any list, nor bound to follow any prescribed order whatever." This gave the employer greater freedom and did not oblige him to hire every one whom the union sent. This provision has been widely copied in a number of industries. It is often accompanied by a further provision that if after a stated period of time, the union is unable to provide a satisfactory

I Mason, Brandeis-A Free Man's Life 301 (I946). 
workman for an opening, the employer is then free to hire a non-union man.

In recent years a still further modification has been introduced in the mass production industries in the form of the so-called "union shop." Here the employer is permitted to hire anyone he wishes, whether nonunion or union. It is merely stipulated that after a given period, the nonunion employees are to join the union if they are to retain their jobs.

Finally there is the so-called "maintenance-of-membership" provision which the National War Labor Board introduced as a compromise during the war. This permits those who were not members of the union on a given date to continue in their status and still hold their jobs. But it also prevents those who were union members on a given date after a transitional "escape period" from resigning from the union or allowing their membership to lapse. While this decision respected the conscientious objections of those who were not originally union members, it prevented those who were already members from changing their minds and bound them by their past decisions. Maintenance of membership, therefore, permitted those who already had strong objections to unionism to stay outside of these organizations and yet not be deprived of their jobs. But it provided that the unions be protected against any future backsliding on the part of their members.

Taken as a whole, therefore, while these modifications of the closed shop soften its impact, they do not change its fundamental character. It is still a device whereby men, as a condition of obtaining or retaining employment, are compelled to join or refrain from leaving a union.

It is important to realize that the determination as to whether or not the closed shop shall be put into effect is now primarily made in individual cases according to the relative bargaining strength of the union and the employer. It is something which the union can impose, along with other terms, under threat of a strike, even though the workers in a particular plant or company are not deeply in its favor. And yet if the demand is once made by union leaders, the rank and file may feel obligated to walk out if it is not granted because the closed shop issue is involved with other terms about which the workers are deeply concerned, or because of loyalty to the general cause of unionism which they may feel is involved, once the issues narrow down to a test of strength. Moreover, once the strike is called, the union does not depend solely upon the loyalty of the immediate workers involved, but it can also call upon the loyalties and resources of workers employed by other companies to impose its will upon the employer in question. It can do this by having these other workers and 
members contribute to the financial support of those out on strike, by manning the picket lines with members largely recruited from outside, and by using these outside unionists to enforce secondary boycotts against the products turned out by the primary company.

It may often be possible, therefore, for union leaders by using, or tacitly threatening to use, these methods to induce employers to yield on the closed shop issue despite the fact that it may not be warmly desired by the men immediately concerned.

On the other hand, if the union is comparatively weak in finances and in outside connections, it may frequently be possible for the employer to prevent the closed shop from coming into being even though the majority of the workers feel an intense need for the protection which it would give. In other words with the issue determined under the power struggle of collective bargaining, the closed shop is frequently obtained where the workers need and desire it the least and is often denied where the workers need and desire it the most.

\section{A POSSIBLE RECONCIIIATION}

I should now like to make a suggestion which may possibly improve the situation. This is to take the issue of the closed shop out of the area of collective bargaining and make it (like the determination as to whether the workers want collective bargaining and if so, through whom) a condition antecedent to collective bargaining. Stated briefly, it consists in letting the workers themselves decide in a free and fair election whether or not they want the closed shop. I hasten to add that this suggestion is in no sense original with me. So far as I know, it was first advanced by $\mathrm{Mr}$. Arthur S. Meyer, the experienced chairman of the New York State Board of Mediation, who deserves a great deal of credit for his informed ingenuity in this as in many other matters.

There is sound precedent for this step in the development which the Wagner Act effected in the field of representation. Prior to that act, it was common practice for employers to refuse to bargain collectively with those who claimed to represent their workers on the ground I) that the employees did not really desire to bargain collectively and 2) that in any event the workers did not desire the particular union concerned or its representatives to act for them. Such for example, was the attitude taken by Judge Gary of the United States Steel Corporation and by other leading steel companies during the big organizing campaign in steel in I9I9.

Now, the tragedy of the situation prior to the passage of the National Labor Relations Act was that there was no mutually acceptable way of 
determining what the workers really wanted. It was always possible for employers to discount the fact of workers signing applications for union membership by either questioning these signatures or by claiming that they were obtained under duress and did not represent the real desires of the workers. In some cases this was true but even when it was false there was no way of proving that this was so.

The result was that commonly the issue as to whether the workers wanted to bargain collectively through given representatives could only be determined by a strike. This not only interrupted production and bred illwill, but it was no sure test as to what the workers wanted. For the results were determined by the comparative strength of the contestants rather than by the real desires of the employees. The strike was indeed a no more effective method of determining these facts than was trial by combat a way of rendering individual justice in feudal times or war a means of deciding equitably between nations.

Now while there are incompletenesses in the Wagner Act and doubtless some abuses in its administration, I submit that it was a mighty step forward when it made the issue of whether or not the workers desired collective bargaining a matter of ascertainable fact rather than one of negotiation by the interested parties or a matter of combat. It provided instead that when the issue was in doubt, the workers themselves should vote on what they wanted in fair and impartially supervised elections. And while the National Labor Relations Board has been bitterly attacked by employers on many grounds I have never known it to be criticized for the way in which it conducted these elections. Whatever other changes may be made in the act, I hardly believe that this feature will be abolished, unless a tidal wave of blind reaction should sweep over our country.

I should like to ask why the same procedure should not be applied to the issue of the closed shop. Instead of letting it be decided by an economic combat, why should it not be decided instead by referendum? Then when the parties sit down to negotiate the terms of a collective agreement they can confine themselves to questions of wages, hours, and working conditions without having the situation muddied by the issue of the closed shop. There may be vital defects in this plan, but I confess that up to date it seems to me to be essentially sound.

There are of course certain procedural details which would be essential to a satisfactory working out of any such plan. First, I take it that it is obvious that in a plant or industry which is adopting collective bargaining for the first time, such a referendum should follow and not precede the election to choose a bargaining agent. If the workers reject the idea of col- 
lective bargaining outright, then there is obviously no need to submit the further issue of the closed shop to the workers.

Second, the issue should only be submitted to referendum if the bargaining representatives who have been chosen demand this of the employers. If, for any reasons, they do not raise the issue, it is probably infinitely better to let the sleeping dogs lie. Employers should not, however, have the power to agree or be forced into agreeing to such an arrangement without referring the matter to the workers by a referendum.

Third, the precise nature of the type of closed shop desired should be carefully and succinctly described by the union in writing and printed on the ballot. The voters themselves would, however, only vote "yes" or "no" on the proposition itself. This requirement that the precise proposition be defined would in turn be a force which would tend to prevent the unions from proposing the more obnoxious forms of the closed shop and would tend to lead to the more reasonable forms being proposed.

Fourth, in view of the tremendous importance which the choice of the closed shop might have upon the affairs of a business, I believe it is only proper that the employers should have the right to acquaint the workers with their own preferences and the reasons why they believe as they do. As a matter of fact, I believe they, as well as national unions, should have that right in connection with the choice of a bargaining unit. But the case for this is much stronger in the issue of the closed shop, where what is at stake is a limitation of the employers' right to hire and retain. Such a right to propagandize should, of course, be exercised soberly by all parties, without undue defamation or excessive expenditures. These are all problems in the political state for which perfect answers have certainly not as yet been found. If we can approximate the restraints which are now imposed in connection with governmental elections we will be doing well and we will certainly be effecting a big improvement over the present situation.

Fifth, if the proposal is adopted, it will, I think be admitted that the workers should be protected against discrimination for any lawful activities during the referendum process.

Sixth, decision by a majority vote would seem the only equitable method. This is the method which we use in political democracy and to require more than this would be to give to members of a minority a greater importance than those of a majority.

Seventh, it would be unfair to have such a decision made once and for all. For if the workers vote the closed shop into being, abuses may develop in its operation which may cause the employees to change their minds. The door should not be closed to such a possible change of opinion. Elec- 
tors should no more be given the power to vote for a perpetual closed shop than to vote for a president for life. Conversely, the workers might turn down a closed shop at one period, but later on the basis of more experience become convinced that it would be desirable. In my judgment they should be given that chance.

Of course these elections should not be allowed to occur so frequently as to keep a plant or company in a continuous electioneering uproar. The chief task of industry is not to hold elections for the delight of the participants, but to get on with the job of production. I would suggest, therefore, that the referenda should not be held more frequently than once every four years and then only at the request of either party. This will make both sides watch their step and be more on guard to prevent possible abuses from developing than if having once won an election, they were to be in power forever more.

Eighth, a pressing issue is what should be the unit for voting. In view of the fact that convictions may vary widely between plants and companies, it would seem unwise to let this issue be decided on an industrywide basis and that instead the unit should not be broader than the company or at most a cluster of companies under unified control and management. This is without prejudice to the possibility that it may be desirable in matters of wages, hours, and other working conditions to have industry-wide bargaining agreements.

Ninth, a very important final issue is whether any such referendum is to apply to concerns which do not now have the closed shop or whether the issue can be opened up afresh in firms where this is already established. To the degree that the unions come to favor any such plan at all, they will obviously tend to want only the former of these alternatives. For this would permit them to hold what they have already obtained through collective bargaining and by strikes and to expand their area of control through elections. And yet this would seem to be unfair in those cases where the workers in given enterprises have tired of the closed shop and would like to make a change. If the principle suggested is sufficiently fair so that workers not yet under it may adopt it for new plants, it would seem only just that workers in plants where it has been adopted should be given the chance to make a change, if they so desire. If this is not done, the opponents of the closed shop may properly object that it is a heads I win, tails you lose proposal.

\section{SOME IMPORTANT CONDITIONS}

There are, however, at least two very important conditions of a substantive nature which should be attached to any such proposal. 
The first is that in order for a union recognized as a bargaining agent to ask for a referendum on the closed shop, it must itself be an "open" union. To combine the closed shop with an artificially "closed" union would permit the insiders to wring monopoly gains from the public and at the same time would force those denied entrance into poorer paid industries where their addition to the social product would be less. It would in my judgment, be both unwise and improper for the state to protect or to foster such an anti-social arrangement. While a large degree of autonomy and self-determination should be granted to industrial units to which the state may properly delegate certain powers of self-government, these should not be allowed to degenerate into an exploitation of the public. The interests of a particular occupational group, particularly in those cases where the demand for the product is relatively inelastic, frequently conflict with those of the public and the public interest is not protected by giving to occupational groups a completely free rein. This is one of the chief objections to a syndicalistic or guild regulated society. We need to keep the occupations open in order to get the best distribution of ability and to produce at non-monopoly prices the goods which the public wants. Just as the existing farmers, doctors, and lawyers should not have the power to determine how many should enter their occupations, nor businessmen the power to bar competitors, so workers should not have the power to lock the gate on qualified men who wish to enter.

As is well known, there are some unions which unreasonably restrict entrance into their ranks by one or more of the following methods: a) by imposing an outright prohibition upon entrance or narrowly restricting it; b) by requiring the payment of unreasonably high initiation fees; c) by requiring a period of apprenticeship appreciably longer than that which is required to learn the trade or perform the tasks required; d) by limiting the number of apprentices so rigidly that not enough workers are provided to meet the demands of the public for products at competitive prices.

The first of these unreasonable requirements can be prevented by an outright prohibition. The others are far more difficult to define and to regulate. Certainly initiation fees of $\$ 250, \$ 500$, and even more than this, are unreasonable and should not be allowed. While it is hard to pick out a definite figure as the dividing line between what is "reasonable" and "unreasonable," in the matter of initiation fees, I am inclined to believe that rough justice would be done by fixing the maximum initiation fee to be charged by a union at approximately $\$ 25$. So far as I know there are few unions in the mass production industries which now charge more than this and the imposition of such a maximum would prevent those now in the union from making it more difficult for latecomers to enter. 
A further protection which in my judgment should be included is to provide that no one should be denied entrance into a union because of race, color, religion, or sex. As is well known some international unions bar Negroes explicitly from membership and in other cases this is done by the local unions. In many other cases this is done not by formal rule, but by accepted, if informal, practice and by a "gentlemen's agreement." In some unions also it is probable that persons of other races and religions are at times denied entrance. There is also a fairly frequent discrimination against women as such.

It is, in my judgment, impossible to justify such discrimination in a democracy which does not believe in dividing its members into citizens of different grades. Under the closed shop if unions in considerable numbers bar Negroes and women from membership, they distinctly limit the employment opportunities of these groups and put them at a grave economic disadvantage. If unions are allowed to expand their membership by including the unwilling, they should not be permitted to restrict their membership by excluding workers because of race, religion, or sex. As a matter of fact this is forbidden by the state labor relations act of Pennsylvania and by the state fair employment practice acts of New York and New Jersey.

A second basic condition should be to provide some impartial review of cases of expulsion from unions operating under these closed shop provisions. Some unions, like the International Typographical Union, carefully safeguard the rights of their members in this matter. There are other unions, however, where, I have become convinced from such study of individual cases as I have been able to make, grave abuses have occurred. These instances of abuse seldom find their way into the literature of trade unionism, but they are no less real. Men have been victimized because they have honestly opposed the policies of officers in charge of the unions and, once expelled, have found it difficult to obtain employment. The granting by the state to the unions of the right to require union membership of the unwilling if it be approved by a majority vote would be a further grant of power by the state which would make of unions even more a quasi-public body than they are now. It is a truism both of ethics and of law, however, that no power or institution should have rights without corresponding duties or privileges without commensurate responsibilities. Men who join a union under these circumstances should be protected

- against capricious or unjust expulsion by the union just as much as against discharge by their employers for union or collective bargaining activities. Such abuses should be directly forbidden by law and some of the neces- 
sary safeguards should be spelled out in the act itself. These might include the provision that a) the charges against any member should be stated in writing; $b$ ) the accused person should have the right to appear in his own defense, engage counsel, and summon and cross-examine witnesses; c) if found guilty, the accused should have the right of appeal to higher union bodies including the international officials; and d) he should also have the right to appeal to local representatives of the National Labor Relations Board or sucn body as administers the act. The costs of such appeal should, of course, be kept very low and every effort made to settle appeals quickly.

The question may well be raised if certain other compensatory protections should not also be introduced into any such law. Among these possible provisions might be a requirement that the union itself must hold periodic and secret elections at least once every four years, and that local, district, and national unions make an annual financial statement to their members as to the amount and general nature of the receipts and expenditures during the given years.

There is little doubt that unions should take more steps toward reform in these lines. Whether they should be required to effect such changes as a prerequisite for having the privilege of having the closed shop made subject to the results of a referendum is, however, a moot point. The mere fact that the workers will have the right to vote on a closed shop and to reject it if they do not like the union in question will force the unions to do some housecleaning in order to gain votes. If this can be done voluntarily, so much the better since it will free the governmental supervisory body from an added administrative load. But if sufficient reform is not effected in this manner within a decent interval of time, then serious thought should at least be given to whether this should not be required by law.

It will be asked, of course, if the unions should not also be required to forego the imposition of restrictive rules and practices or what is popularly known as "feather-bedding." There is little doubt that there are some such abuses. It is highly desirable that these be removed. The subject is, however, so complicated and it is so hard to define what are "reasonable" and what are "unreasonable" restrictions, that it would not seem wise to include them in the proposed act. It is important not to overburden the administrative machinery and not all abuses can be removed at any one time. Gross and unreasonable restrictions, particularly when they involve the fixation of prices, can still be prosecuted under the Sherman Act as was done when Thurman Arnold was in charge of this work. Perhaps it 
would be well to leave the matter in this status for a period until it is seen whether the situation is being cleaned up.

I am aware that the zealots on both sides of this issue of the closed shop and of unionism in general will probably regard this proposal as a subterfuge which avoids a decision on the relative merits of unionism and the closed shop as such. Those who regard unionism as essentially evil in its effects upon production and upon the relationships between employer and worker and who believe that under no circumstances should a man be forced to join a private association against his will, are likely to object to letting such a moral issue be decided by a majority vote of the workers. To these men, unionism is itself something evil which should be stamped out and even if the workers want to extend it, no compromise should be made.

The more extreme advocates of unionism and the closed shop may take a similar position. Believing firmly in the righteousness of their cause, they are likely to believe that unionism is "good" for all workers, irrespective of whether the workers themselves believe it to be or not. This school may, therefore, favor the compulsory extension of the closed shop by collective bargaining or legal enactment and scorn a process under which the workers, exposed to opposing propaganda, might decide against them.

There may also be unionists who will think that the conditions which I have attached are too onerous. Many, for example, will probably not want the principle of the referendum applied to those plants which already have the closed shop since they may be fearful that under such an arrangement unionism will lose more than it will gain. They may also oppose action by the state in keeping the unions "open" and in protecting the members against unjust expulsion. They may, therefore, regard the practical price of these conditions as too great for any benefits which unions may reap.

Conversely, there may be many employers who believe that they will have a better practical chance to overthrow the closed shop through state and national legislation forbidding it than to take the chance of having it voted in as well as out by the worker.

Both groups may, therefore, on principle and in practice, reject the method of popular choice as the advocates and opponents of slavery finally came to reject the doctrine of "squatter sovereignty" advanced between 1848 and $186 \circ$ by Lewis Cass and finally by Stephen A. Douglas. Cass and Douglas strove to make slavery a local issue under which the inhabitants of a territory could decide for themselves by majority vote 
whether or not they would permit the institution of slavery within their borders. The southern advocates of slavery and their northern allies were not content with this. They wanted to extend slavery into the territories even though the inhabitants did not want it and finally they legalized their position through the Dred Scott decision. Indeed many of them wanted to extend slavery as a national institution into the free states themselves as was evidenced in the boast of Senator Toombs, of Georgia, that he intended to call the roll of his slaves from the foot of Bunker Hill monument. On the other hand, Lincoln and his followers wanted to prevent, by national action, the spreading of slavery into the territories and the extreme abolitionists, such as John Brown, wanted to free the slaves in the southern states. Under the terrific pressure of these conflicting forces, the attempt of Douglas and his followers to localize the problem by letting the territories decide for themselves was defeated.

And yet it is permissible to ask as George Fort Milton, Avery Craven, and J. C. Randall have done, whether the program of Douglas was not after all, wiser than it has seemed. Because the extremists on both sides would not let it operate, we got the Civil War which Douglas was trying to avoid. This war freed the slaves which was a great ethical gain, and it preserved the Union, but it did so at a terrific cost in life, hardship, and bitterness between sections which even now, after the passage of nearly a century, is still acute. And while the Negroes have been freed, they are still grievously oppressed politically, economically, and socially. It is, at least, possible that we might have made more enduring progress if we had moved less hastily and drastically. And yet to do this, the extremists on both sides would have had to maintain a patience and a moderation which in practice it is hard for those with sharply differing ideologies to display.

It is well to remember the sad, but trenchant, dictum which Mr. Justice Holmes expressed in his fascinating correspondence with Sir Frederick Pollock: "As between two groups, each equally convinced with the righteousness of its own cause, I see no ultimate arbitrament but force." Perhaps this is so, but if it is true, it means that incessant civil and international war is the inevitable consequence of sharp differences of opinion and of moral judgments. I cannot believe that this is either necessary or desirable in the present instance. The peace, harmony, and high productivity of this nation are far more important than the issue of the closed shop. Certainly this is a far less pressing moral issue than was slavery. It would be a great mistake to let ourselves be torn apart by strikes to establish the closed shop or by blanket legislative prohibitions of its existence. There seems to me to be sound merit, therefore, in Mr. Meyer's proposal to let 
the issue be decided plant by plant and company by company in the timehonored and democratic way of free elections. It is because of our free elections and our willingness to abide by the results that we do not have revolutions or the secret police in this country. We have built up a political process by which moral issues can be submitted to the people and their judgments recorded and put into effect. We have gone on the basis that as Mr. Justice Holmes once said, the "test of truth is its ability to establish itself in the competition of the market." This competition should be freed from gross misrepresentation and coercive force but can we not trust in the essential fairness of men when given the facts and the arguments to winnow out the truth from error? Men and causes which depend upon getting the permanent approval of the voters have to purge themselves of gross abuses in order to survive. Public opinion operates to keep our political parties comparatively decent. If allowed to express itself, it would, I think, purge unionism from many of its abuses and help further to protect the individual workers from being victimized by their employers.

Most young men tend to be impatient with what the lawyers term procedural matters and to be far more interested instead in substantive issues. Only the latter seem to the young to have vitality. But as time passes and a man grows older, it dawns upon him that a great part of our progress has been made through transforming substantive issues of conflict into accepted matters of procedure. For it is in this way the society peacefully disposes of issues which, if not so handled, would tear it apart. May there not be a moral guide for action in this fact? 